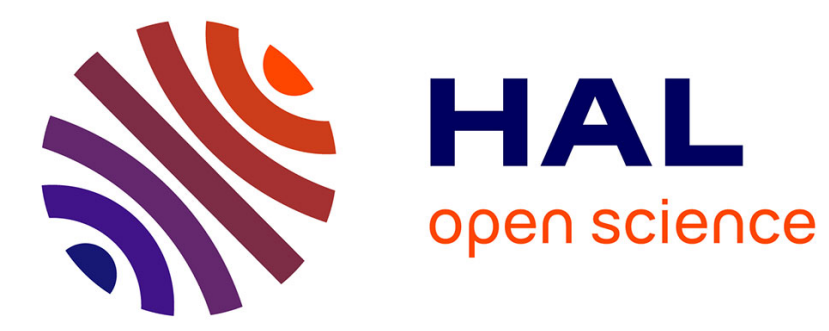

\title{
Optimization of a power electronic structure for hybrid Fuel Cell/Ultracapacitors vehicle
}

\author{
M. Kamali-Nejad, T. Azib, G. Remy, O. Béthoux, Claude Marchand
}

\section{To cite this version:}

M. Kamali-Nejad, T. Azib, G. Remy, O. Béthoux, Claude Marchand. Optimization of a power electronic structure for hybrid Fuel Cell/Ultracapacitors vehicle. 2010 IEEE Vehicle Power and Propulsion Conference (VPPC), Sep 2010, Lille, France. pp.1-6, 10.1109/vppc.2010.5729165 . hal-02054624

\section{HAL Id: hal-02054624 \\ https://hal.science/hal-02054624}

Submitted on 1 Mar 2019

HAL is a multi-disciplinary open access archive for the deposit and dissemination of scientific research documents, whether they are published or not. The documents may come from teaching and research institutions in France or abroad, or from public or private research centers.
L'archive ouverte pluridisciplinaire HAL, est destinée au dépôt et à la diffusion de documents scientifiques de niveau recherche, publiés ou non, émanant des établissements d'enseignement et de recherche français ou étrangers, des laboratoires publics ou privés. 


\section{Accepted Manuscript} (VTS).

Optimization of a power electronic structure for hybrid Fuel Cell/Ultracapacitors vehicle

M. Kamali-Nejad, T. Azib, G. Remy, O. Bethoux and C. Marchand

DOI:

$\underline{10.1109 / V P P C .2010 .5729165}$

Reference:

Publisher: IEEE

To appear in: IEEE Conferences

Conference date: $\quad$ 1-3 September 2010, Lille, France

Date of Publication: $\quad 10$ March 2011 (available on line)

Please cite this article as:

M. Kamali-Nejad, T. Azib, G. Remy, O. Bethoux and C. Marchand, "Optimization of a power electronic structure for hybrid Fuel Cell/Ultracapacitors vehicle", 2010 IEEE Vehicle Power and Propulsion Conference, Lille, 2010, pp. 1-6.

doi: 10.1109/VPPC.2010.5729165.

URL:

http://ieeexplore.ieee.org/stamp/stamp.jsp?tp=\&arnumber=5729165\&isnumber=5728974

Document Version: $\quad$ Early version, also known as pre-print

This is a PDF file of an unedited manuscript that has been accepted for publication. As a service to our customers we are providing this early version of the manuscript. The manuscript will undergo copyediting, typesetting, and review of the resulting proof before it is published in its final form. Please note that during the production process errors may be discovered which could affect the content, and all legal disclaimers that apply to the journal pertain. 


\title{
Optimization of a Power Electronic Structure for Hybrid Fuel Cell/Ultracapacitors Vehicle
}

\author{
M. Kamali-Nejad, T. Azib, G. Remy, Member, IEEE, O. Bethoux, Member, IEEE, and C. Marchand, Member, IEEE \\ Laboratoire de Génie Electrique de Paris (LGEP) / SPEE-Labs, CNRS UMR 8507; SUPELEC; Université Pierre et Marie \\ Curie P6; Université Paris-Sud 11; 11 rue Joliot Curie, Plateau de Moulon, F91192 Gif sur Yvette CEDEX. (Toufik AZIB, \\ phone: +33(0)169-851-672; fax: +33(0)169-418-318; \\ ghislain.remy@lgep.supelec.fr, olivier.bethoux@lgep.supelec.fr
}

\begin{abstract}
This paper deals with the optimization of a parallel hybrid Fuel Cell (FC)/ Ultracapacitors (UCs) power source for automotive applications. The aim of this hybridization and its control are to fulfil the load requirements as well as to comply with the component constraints (high efficiency, reduced weight and cost, etc.). First, a classical hybrid architecture using FC/UCs and a two-converter structure is presented. After that, power requirements for automotive applications are analyzed, and the load power demands for the FC/UCs sources are deduced. Secondly, the model-based design approach is used for the optimization, and a selection of the main components to be optimized is presented. Thus, the simulation model and the control strategy are detailed. This model has been validated experimentally. Finally, an optimization algorithm is designed using Parallel Computing and the Genetic Algorithm toolbox of Matlab/Simulink. The retained criterion is based on the reduction of the total volume of the system.
\end{abstract}

\section{INTRODUCTION}

Nowadays, with more and more severe emission standards and the reduction of global fuel supplies, electric/ hybrid vehicles are a very viable technology. It offers a significant potential to meet both fuel economy and emission cleaning demands, particularly the Fuel Cell Hybrid Electric vehicle FCHEV [1]. This system combines a fuel cell power system with an energy storage system (ESS) as a power source. The ESS (e.g., batteries or ultracapacitors) helps the fuel cell to supply peak power to the electric drive system during acceleration and recovers energy during deceleration, which consequently improves the efficiency and dynamic characteristics of the power system [2]. On the other hand, the ultracapacitor FCHEV has three major advantages over a battery FCHEV, satisfying almost the same packaging and cost requirements: higher energy efficiency, better accelerating performance and extended fuel cell life [2], [3]. However, the energy storage system increases the complexity of the overall power plant, the control design having an important effect on system performance.

As well as the control design, it is very important for component sizing to be taken into account in order to reduce installation investment costs and to achieve good overall performance, which is the main objective of this work.

Firstly, in this paper, a classical hybrid architecture using FC/UCs and a two-converter structure is presented. Then, power requirements for automotive applications are analyzed using a frequency decomposition of the load power demands for the FC/UCs sources. Then, a selection of the main components to be optimized is presented using an energy repartition calculation. As the optimization used a modelbased design approach, the simulation model and the control strategy are detailed. This model has been validated experimentally using a Nexa Ballard PEMFC as main source and BOOSTCAP Maxwell ultracapacitors as auxiliary source. Finally, an optimization algorithm is introduced and configured for Parallel Computing using the Genetic Algorithm toolbox of Matlab/Simulink. The retained criterion is based on the reduction of the total system volume.

\section{HYBRID VEHICLE STRUCTURE}

For the powertrain of hybrid vehicles using fuel cells as main power source, different hybrid fuel cell system configurations have been suggested and investigated (series, parallel, and cascade) [4], [5], [6]. It has also been proven that the parallel structure is most advantageous [5], [6]: fewer component constraints, easy energy management and good reliability.

\section{A. Two-converter parallel structure}

Among the major topologies of parallel structures for FC/SCs hybrid power system, the two-converter parallel structure (Fig. 1) is the most used [6]-[9]. Some of the advantages are: no pollution, no noise, constant DC bus, simple control, improved FC lifetime, reversible energy conversion.

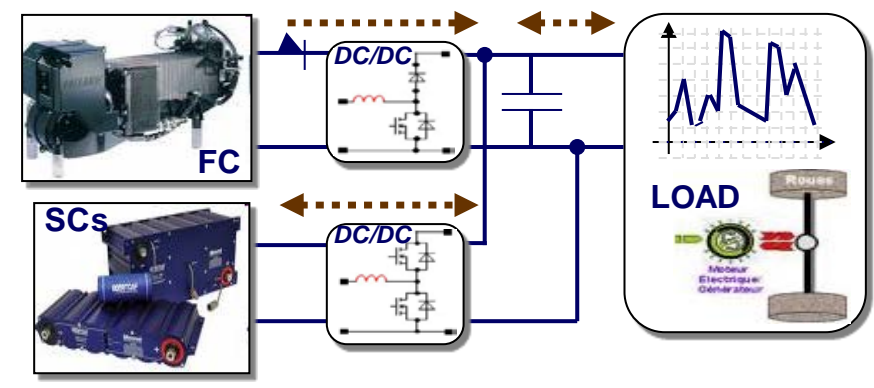

Fig. 1. Two-converter parallel structure for FC/UCs hybrid power system. 
Accepted article for publication in 2010 IEEE Vehicle Power and Propulsion Conference, Lille, France - Citation information: doi: 10.1109/VPPC.2010.5729165

Available online 10 March 2011

\section{B. Power load reference profile}

The needed car power is mainly due to speed variations, tyre friction dissipation, aerodynamics dissipation and mass elevation. This power, $\mathrm{P}_{\text {motor, }}$ can be expressed as:

$P_{\text {motor }}=V\left(C_{r} M g \cos (\alpha)+M g \sin (\alpha)+M \frac{d V}{d t}+\frac{1}{2} \rho S C_{x} V^{2}\right)$

Where:

$\mathrm{V}$ and $\mathrm{M}$ are the vehicle speed and mass (in $\mathrm{m} . \mathrm{s}^{-1}$ and $\mathrm{kg}$ ); $\alpha$ is the road angle with an horizontal line (in rad); $\mathrm{C}_{\mathrm{r}}$ and $\mathrm{C}_{\mathrm{x}}$ are the friction and aerodynamic coefficients; $\rho$ is the air density (in $\mathrm{kg} . \mathrm{m}^{-3}$ ) and $g$ is the g-force (in $\mathrm{m} . \mathrm{s}^{-2}$ ) $\mathrm{S}$ is the front surface area (in $\mathrm{m}^{2}$ ).

$\mathrm{M}=1000 ; \mathrm{g}=9.81 ; \alpha=0 ; \mathrm{Cr}=0.01 ; \mathrm{Cx}=0.30 ; \rho=1.225 ; \mathrm{S}=2.5$

These values correspond to a mid-size car adapted to urban transportation. Thus, the vehicle power demand can be determined by the driver's requirements. Indeed, European light duty vehicles have to face the New European Driving Cycle (NEDC) which represents the typical usage of a car in Europe. The NEDC consists of repeated urban cycles (called ECE-15 driving cycle) and an Extra-Urban driving cycle, or EUDC. Fig. 2 shows the ECE-15 cycle with the speed and the power demand of a car following a flat road.

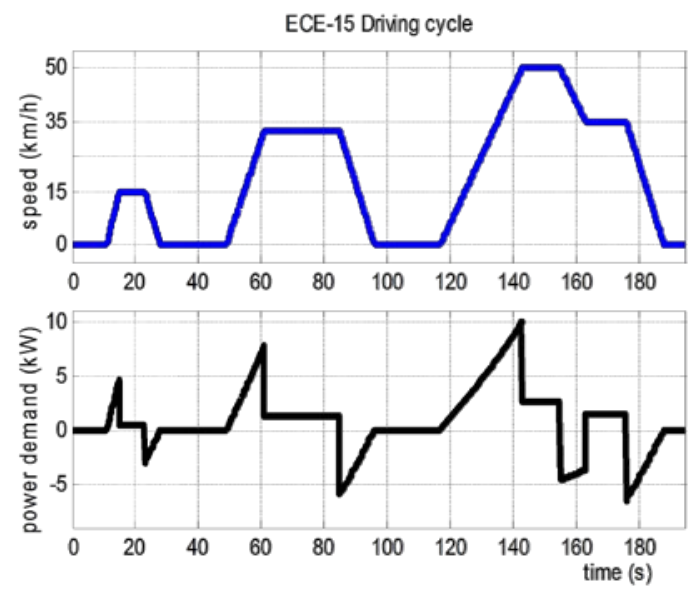

Fig. 2. ECE-15 Driving Cycle.

Sudden power changes can be noticed each time the driver requires a speed change. In this example, the car's average power is only of $0.72 \mathrm{~kW}$, whereas the peak power reaches roughly $10 \mathrm{~kW}$, which means a $13.7\left(\mathrm{P}_{\max } / \mathrm{P}_{\text {average }}\right)$ ratio. Finally, the power source optimization of the hybrid sources has to fulfill both requirements. These requirements are included in a model for optimization purpose.

\section{MODEL DESIGN FOR OPTIMIZATION}

Nowadays, the Model-Based Design approach is widely used to design systems from simulation to real-time application [10]. The optimization strategy uses this ModelBased Design approach to accelerate the design of hybrid vehicle regarding various requirements [11].

In this paper, we focus on the design of a FC/UC hybrid vehicle. The main principle of such a design approach is to optimize the parameter values of a model that has been previously validated using experimental results: to be more precise, a Matlab/Simulink model of the hybrid vehicle is designed including the control strategy. The model parameters are identified using a test bench of about $1 \mathrm{~kW}$, and simulation results are compared to the experimental results. Then, the $1 \mathrm{~kW}$ Model is extended to optimize the system parameters of a $10 \mathrm{~kW}$ car's power regarding the NEDC requirements. Of course, the parameter validity domain has to be carefully considered. Nevertheless, such method allows for greatly reducing the size of the test bench.

In the following section, the model and the control used are described. Then, some experimental validations of the presented system model are depicted.

\section{A. Model description}

The model-based design approach is used to facilitate the global optimization of the system. Indeed, the simulation includes the component models and their associated controls, and it allows to evaluate the system performances for a requested load on each component and to estimate the system’s stability.

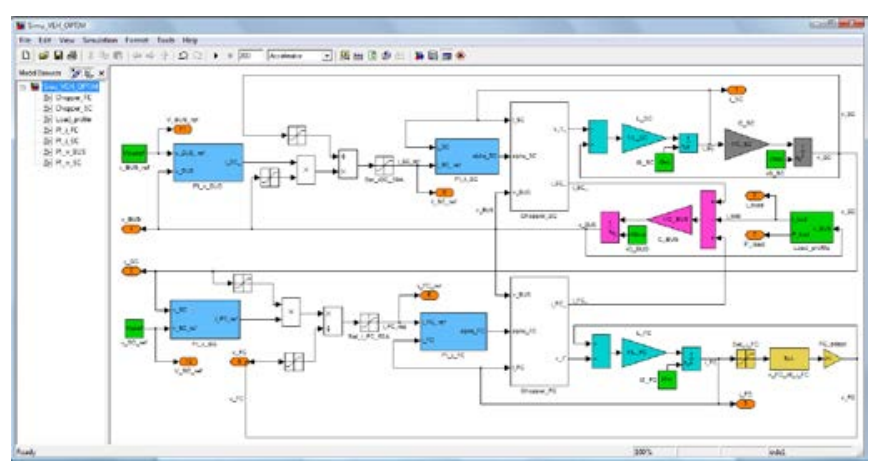

Fig. 3. Model and Control Scheme using Simulink.

\section{Ultracapacitors model}

Various ultracapacitor models can be found in literature, especially for hybrid systems [12], [13]. Classically, an ultracapacitor theoretical model uses a transmission line with the voltage ( $\mathrm{V}_{\mathrm{SC}}$ ) dependent on distributed capacitance [14].

However, to take into account the supercapacitor behavior during charge and discharge and to preserve a sufficient accuracy, a RC model is utilized to describe the nonlinear electrode behavior:

- The resistor $\mathrm{R}$ models the supercapacitor ohmic loss, usually called equivalent series resistor (ESR).

- The capacitor C represents the supercapacitor capacitance during charging and discharging effects. 
Accepted article for publication in 2010 IEEE Vehicle Power and Propulsion Conference, Lille, France - Citation information: doi: 10.1109/VPPC.2010.5729165

Available online 10 March 2011

The RC parameter values are extracted directly from the manufacturer's datasheets.

\section{Fuel Cell model}

In low dynamic conditions, the fuel cell characteristics can be considered as a voltage source with ohmic, kinetic and mass transfer resistances [15]. Consequently, the fuel cell can be connected either in series with a current source, which is the case in the two-converter structure $(\mathrm{L}$ in series with the FC) or in parallel to the DC bus, which is a perfect voltage source with its associated capacitor $\mathrm{C}_{\mathrm{Bus}}$. Of course, the capacitor value has to remain low in order to prevent difficult starting procedures.

Furthermore, the fuel cell system is a complex device with many auxiliary components. Hence, a significant part of the electrical power generated is used internally, which means that the real stack current is greater than $\mathrm{i}_{\mathrm{FC}}$. More precisely, the relationship between the FC voltage $\mathrm{v}_{\mathrm{FC}}$ and the output current $\mathrm{i}_{\mathrm{FC}}$ is given by the following equations:

$V_{F C}=N\left(E_{\text {Cell }}-R \cdot j_{\text {stack }}-A \cdot \ln \left(j_{\text {stack }}+j_{l}\right)-m \exp \left(n j_{\text {Stack }}\right)\right)$

$$
j_{\text {Stack }}=\frac{I_{\text {Stack }}}{A_{\text {Cell }}} \text {, and here: } I_{\text {Stack }}=\alpha+(1+\beta) I_{F C}+\gamma\left(I_{F C}\right)^{2}
$$

Where $A_{\text {Cell }}$ is the area of each cell, $\mathrm{N}$ is the stack cell number, $\mathrm{E}_{\text {cell }}$ is the reversible cell voltage, $\mathrm{R}$ is the membrane area specific resistance; $\mathrm{A}$ is the Tafel coefficient; and $\mathrm{m}$ and $\mathrm{n}$ are the two coefficients of the mass transfer equation [16]. Fig. 4 shows the experimental characteristics and the simulated model of the studied FC.

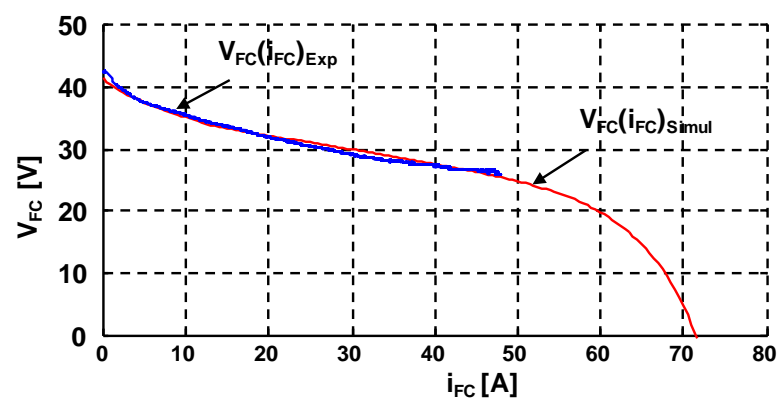

Fig. 4. PV Characteristics.

The experimental set-up of the hybrid Fuel Cell / Ultracapacitors power source uses a Nexa BALLARD PEM fuel cell stack of $1200 \mathrm{~W}$ as the main source, as shown in Figure 5. The auxiliary source is obtained with a Maxwell SC module associating two modules in series: Maxwell BMOD0250 (each module is achieved with a series connection of six individual "2.7V, 1500F" elements).



Fig. 5. The components of the experimental bench.

A ZS electronic load ZS1806 of $1800 \mathrm{~W}$ (i= 0....150A / $\mathrm{V}=0 \ldots . .60 \mathrm{~V})$ fulfills the power load demands. The power converters DC/DC are realized with standard IGBT modules (SEMITRANS: SKM50GB123D). A real-time dSPACE DS1104 controller board is used to implement the energy management control strategy designed with Matlab/ Simulink.

\section{B. Control description}

The two-converter structure consists in associating a static converter and a control loop to each power source (Fig. 1). This control strategy generates a large number of degrees of freedom in the control design (Fig. 6). This classical hybrid structure has been validated in various works [7]-[9], [17].

The control strategy is based on a power decoupling strategy in the frequency domain of the power source. This energy-management strategy fulfills the fast energy demands of the load and respects the integrity of each source. The full details of the control strategy have been published in previous work [17].

\section{Optimization algorithm}

In literature, optimization of a mixed continuous and discrete model is known as hard optimization [18]. The four most widely known metaheuristics for hard optimization are [19]:

- The simulated annealing method;

- The tabu search;

- The ant colony algorithms;

- The genetic and evolutionary algorithms.

Some common features clearly appear in most metaheuristics, such as the use of diversification, to force the exploration of regions of the search space, rarely visited until now, and the use of intensification, to go thoroughly into some promising regions. One common drawback for most metaheuristics still is the delicate tuning of numerous parameters; theoretical results available by now are not sufficient to really help, in practice, the user facing a new hard optimization problem.

Among them, we have chosen the Genetic Algorithms available in MATLAB ${ }^{\circledR}$ products. Because it can be used for 
Accepted article for publication in 2010 IEEE Vehicle Power and Propulsion Conference, Lille, France - Citation information: doi: 10.1109/VPPC.2010.5729165

Available online 10 March 2011

such problems that are difficult to solve with traditional optimization techniques, including problems that are not well defined or are difficult to model mathematically. Precisely, GA can be used when computation of the objective function is discontinuous, highly nonlinear, stochastic, or has unreliable or undefined derivatives. Some of the GA advantages over the traditional numerical optimization approaches are related to:

- The optimization with continuous or discrete parameters;

- The derivative information, which is not requested;

- The simultaneously searches from a wide sampling of the cost surface;

- $\quad$ The well suited implementation for parallel computers.

Nevertheless, in the field of continuous optimization, there is a significant arsenal of traditional methods used for global optimization [20], but these techniques are often ineffective if the objective function does not possess a particular structural property, such as convexity. In order to overstep this convergence issue and to reduce the GA calculation time, a Monte-Carlo analysis can be performed on the system. Indeed, it allows GA to start with initial parameter values leading close to the solution.

Besides, the definition of the optimization problem is often supplemented by the constraints. All the parameters of the adopted solutions must satisfy these constraints, or otherwise these solutions are not realizable. But including constraints in the optimization induces a larger time calculation for the GA [21]-[23]. Then the problem formulation can be reconsidered in order to avoid formulations with constraints [24]. Indeed, some transformations are critical in matching a problem to the characteristics of an algorithm.

In the studied case, constraints can be avoided using penalties method on the model [25]. However, even if stochastic methods such as genetic algorithms can be easily implemented, algorithm parameter tuning is highly important to achieve the global optimum.

The advantage of this kind of algorithm is that, by creating a large enough population, the probability of finding the global minimum point is higher. The drawback is the time needed to run such an algorithm [26]. Therefore the parameters should be well tuned. In our case, two main strategies are chosen in order to tune the GA.

Firstly, we performed a Monte Carlo (MC) simulation in order to put forward an initial population to GA. This fact will help GA in order to converge to the global optimum. Performing a MC simulation with a large population and selecting the best points is a better way for creating an initial population for GA compared with the random creation of an initial population. To perform the MC simulation, a random value is generated for each variable by using a classical generator as an extended cellular automata generator [27].
When tackling the multi-criteria optimization of a device in electrical engineering, the exhaustive sampling of the Pareto optimal front implies the use of complex and time-consuming algorithms that are unpractical from the industrial viewpoint.

TABLE I

DETAILS OF THE GA OBJECTIVE FunCTIONS

\begin{tabular}{cccc}
\hline \hline Parameter & Cost & Volume & Weight \\
\hline \hline UC & $12 \$ / \mathrm{kW}$ & $0.21 \mathrm{~L} / \mathrm{kW}$ & $0.32 \mathrm{~kg} / \mathrm{kW}$ \\
\hline FC & $254 \$ / \mathrm{kW}$ & $1.49 \mathrm{~L} / \mathrm{kW}$ & $1.44 \mathrm{~kg} / \mathrm{kW}$ \\
\hline \multirow{3}{*}{ L_UC } & $58.67(\$)+$ & $0.25(\mathrm{~L})+$ & $2.03(\mathrm{~kg})+$ \\
& $54.34(\$) \times$ & $0.73(\mathrm{~L}) \times$ & $2.63(\mathrm{~kg}) \times$ \\
& Energy $(\mathrm{J})$ & Energy $(\mathrm{J})$ & Energy $(\mathrm{J})$ \\
\hline \multirow{3}{*}{ L_FC } & $58.67(\$)+$ & $0.25(\mathrm{~L})+$ & $2.03(\mathrm{~kg})+$ \\
& $54.34(\$) \times$ & $0.73(\mathrm{~L}) \times$ & $2.63(\mathrm{~kg}) \times$ \\
& Energy $(\mathrm{J})$ & Energy $(\mathrm{J})$ & Energy $(\mathrm{J})$ \\
\hline \multirow{2}{*}{ C_BUS } & $2.36(\$)+$ & & - \\
& $0.18(\$) \times$ & - & - \\
\hline \hline
\end{tabular}

In several cases, however, the accurate identification of a few non-dominated solutions is often sufficient for design purposes. An evolutionary methodology of the lowest order, dealing with a small number of individuals, is proposed to obtain a cost-effective approximation of non-dominated solutions. The optimal design of a hybrid power source, based on the optimization of cost, volume, weight and performance of the device, is obtained in Table I.

\section{OPTIMIZATION RESULTS}

In our case, after performing the Monte Carlo simulation with a 5000 population, 24 best points are selected among the results and they are put into GA as part of the initial population. The rest of the initial population (40 points) is created by GA using a uniform distribution. This allows GA to sweep a wider search zone.

Secondly, the other parameters of GA such as mutation rate, elite count, selection function, etc., are chosen so as to provide a maximum chance for GA to achieve the global optimum.

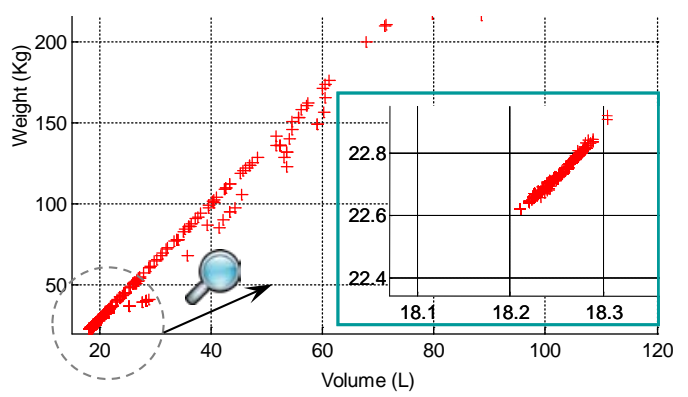

Fig. 6. Optimization results of the Weight/Volume objective functions. 
Accepted article for publication in 2010 IEEE Vehicle Power and Propulsion Conference, Lille, France - Citation information: doi: 10.1109/VPPC.2010.5729165

Available online 10 March 2011

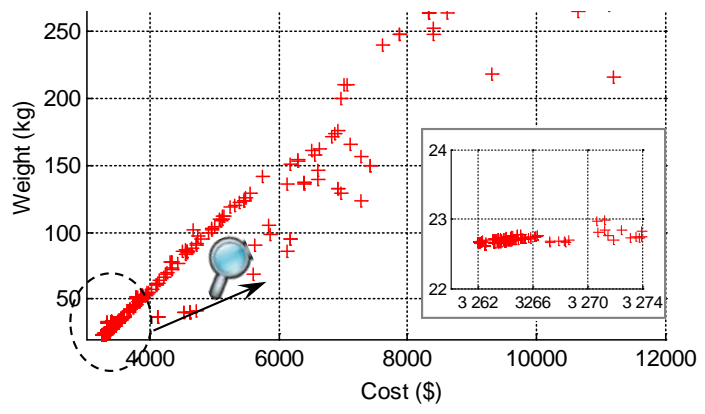

Fig. 7. Optimization results of the Weight/Cost objective functions.

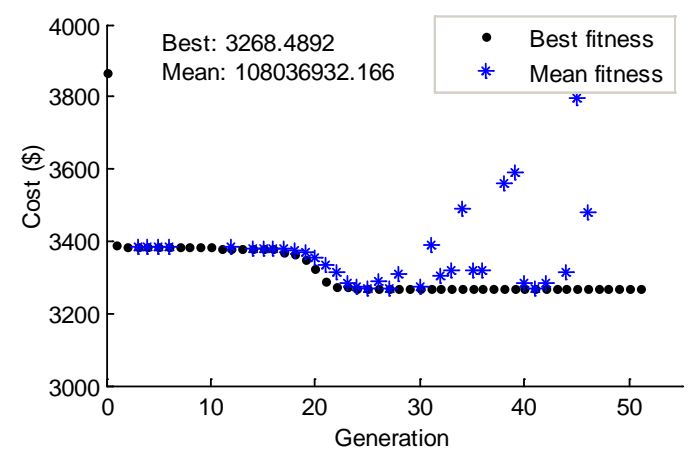

Fig. 8. Optimization results of the cost function of the number of generation.

The optimized values of the system parameters are depicted in Table II, and the obtained results in Table III:

TABLE II

GENETIC ALGORITHM PARAMETERS

\begin{tabular}{cc|cc}
\hline \hline Parameter & \multicolumn{3}{c}{ Value } \\
\hline $\begin{array}{c}\text { Number of } \\
\text { Variables }\end{array}$ & \multicolumn{2}{c}{ [N_FC, S_FC, L_FC, C_SC, L_SC, C_BUS]; } \\
\hline $\begin{array}{c}\text { lower bound } \\
{[36,0.01,1 \mathrm{e}-5,1,1 \mathrm{e}-5,1 \mathrm{e}-3]}\end{array}$ \\
\hline Upper bound & {$[120,0.5,50 \mathrm{e}-3,1 \mathrm{e}, 50 \mathrm{e}-3,1]$} \\
\hline \hline Parameter & Value & Parameter & Value \\
\hline $\begin{array}{c}\text { Population } \\
\text { Size }\end{array}$ & 64 & Creation Fcn & $\begin{array}{c}\text { Creation } \\
\text { uniform }\end{array}$ \\
\hline $\begin{array}{c}\text { Elite Count } \\
\text { Generations }\end{array}$ & 4 & Fitness Scaling & $\begin{array}{c}\text { Fit scaling rank } \\
\text { Fcn }\end{array}$ \\
\hline $\begin{array}{c}\text { Crossover } \\
\text { Fraction }\end{array}$ & 0.8 & Crossover Fcn & $\begin{array}{c}\text { Crossover two } \\
\text { point }\end{array}$ \\
\hline Use Parallel & always & \multicolumn{3}{c}{} \\
\hline \hline
\end{tabular}

TABLE III

OBTAINED SOLUTION BY GA

\begin{tabular}{lc|cc}
\hline \hline Parameter & Value & Parameter & Value \\
\hline N_FC & 70 & C_UC & $971.32 \mathrm{~F}$ \\
S_FC & $0.4949 \mathrm{~cm}^{2}$ & L_UC & $80.97 \mu \mathrm{H}$ \\
L_FC & $44.95 \mu \mathrm{H}$ & C_BUS & $0.5219 \mathrm{~F}$ \\
\hline \hline \multicolumn{2}{c|}{ Cost function $(\$)$} & \multicolumn{2}{c}{ Weight function $(\mathrm{kg})$} \\
\hline \multicolumn{2}{c}{ 3265 \$ } & \multicolumn{2}{c}{$22.622 \mathrm{~kg}$} \\
\hline \hline
\end{tabular}

V. CONCLUSION

In this paper, an optimization of a parallel hybrid Fuel Cell (FC)/ Ultracapacitors (UCs) power sources for automotive applications has been described. A Model-Based Design approach has been used to accelerate the design and to reduce the size of the test bench. An optimization using a paralleled Genetic Algorithm has been performed. The aim is to find the optimized value of the system parameters within the lowest possible volume in order to fulfill a NEC-15 for a mid-size car. The final paper will include the results of the multiobjectives regarding the volume, the cost, the weight and the energy consumption of the car.

\section{REFERENCES}

[1] D. H. Phuc, P. Raksincharoensak, N. Masao, M.Suzuki, "Control Strategy for Hybrid Electric Vehicles Based on Driver Vehicle Following Model”, SICE-ICASE International Joint Conference, Busan, Korea, October, 2006.

[2] S.-J. AN, K. I. LEE and T.-J. KIM,” performance analysis according to the combination of energy storage system for fuel cell hybrid vehicle," International Journal of Automotive Technology, Vol. 9, No. 1, pp. 111-118, 2008

[3] P. Barrade, A. Rufer, "The use of supercapacitors for energy storage in traction systems, ” IEEE, Vehicular Power and Propulsion Symposium, VPP'04, 6-8 Oct.2004.

[4] A. Hajizadeh, and M.A. Golkar, "Intelligent power management strategy of hybrid distributed generation system”, Elsevier, Electrical Power and Energy Systems, Vol.29, 2007, pp. 783-795.

[5] M. Cacciato, F. Caricchi, F. Giuhlii, and E. Santini, “A critical evaluation and design of bi-directional DC/DC converters for supercapacitors interfacing in fuel cell applications", in Proc. Industry Applications Conf., IEEE IAS 2004, Oct. 2004, Vol.2, pp. 1127-1133.

[6] Z. Jiang, L. Gao, M.J. Blackwelder, and R.A. Dougal, "Design and,experimental tests of control strategies for active hybrid fuel cell/battery power sources”, J. Power Sources, Vol.130, 2004, pp. 163171.

[7] P. Thounthong, S. Rael, and B. Davat, "Control strategy of fuel cell/supercapacitors hybrid power sources for electric vehicle," Elsevier, Journal of Power Sources, Vol.158, 2006, pp. 806-814.

[8] J.N. Marie-Francoise, H. Gualous, R. Outbib, and A. Berthon, "42V Power Net with supercapacitor and battery for automotive applications" Elsevier, Journal of Power Sources, Vol.143, 2005, pp. 275-283.

[9] T. Azib, O. Bethoux, C. Marchand, E. Berthelot, "Supercapacitors for Power Assistance in Hybrid Power Source with Fuel Cell ", IEEEIECON 2009, the 35th Annual Conference of the IEEE Industrial Electronics Society, PORTO, PT, 3 November 2009, pp. 11-18,

[10] G. Nicolescu, P.J. Mosterman, Model-Based Design for Embedded Systems, CRC Press, Nov 2009, pp. 383-718.

[11] J. Marco and E. Cacciatori, "The Use of Model Based Design Techniques in the Design of Hybrid Electric Vehicles," in Automotive Electronics, 2007 3rd Institution of Engineering and Technology Conference on, 2007, pp. 1-10.

[12] M. Ehsani, Y. Gao, S.E. Gay, and A. Emadi, Modern Electric, Hybrid Electric, and Fuel Cell Vehicles Fundamentals, Theory, and Design, CRC Press, 2005.

[13] J. Bauman, M. Karezani, “A comparative study of fuel cell-battery, fuel cell-ultracapacitor, and fuel cell-battery-ultracapacitor vehicles,” IEEE Trans. Vehicular Technology, Vol .57, No.2, pp. 760-769, Mar. 2008.

[14] F. Rafik, H. Gualous, R. Gallay, M. Karmous, and A. Berthon, "Contribution to the sizing of supercapacitors and their applications," IEEE-ESCAP’04. Conference, 2004.

[15] F. Barbir, PEM Fuel Cells-Theory and Practice, Burlington, MA: Elsevier Academic Press, Jun. 2005.

[16] W. He, G. Lin, T.V. Nguyen, "Diagnostic tool to detect electrode flooding in proton exchange membrane fuel cells”, AIChE J., Vol. 49, No.12, 2003.

[17] T. Azib, O. Bethoux, G. Remy, C. Marchand, E. Berthelot, "An Innovative Control Strategy of a Single Converter for Hybrid Fuel 
Accepted article for publication in 2010 IEEE Vehicle Power and Propulsion Conference, Lille, France - Citation information: doi: 10.1109/VPPC.2010.5729165

Available online 10 March 2011

Cell/Supercapacitors Power Source," IEEE Transactions on Industrial Electronics, 2010, pp. 1-8, accepted, in edition.

[18] C.A. Floudas and P.M. Pardalos, Encyclopedia of Optimization, Springer Reference, 2nd Ed Sept 2008

[19] F. Glover, G.A. Kochenberger, Handbook of Metaheuristics, Kluwer Academic Pub, International Series in Operations Research \& Management Science, 2003.

[20] R. Horst and P.M. Pardolos, Handbook of Global Optimization, Kluwer Academic Publishers, 1995.

[21] A. R. Conn, N. I. M. Gould, and P. L. Toint, “A Globally Convergent Augmented Lagrangian Algorithm for Optimization with General Constraints and Simple Bounds”, SIAM Journal on Numerical Analysis, Vol.28, pp. 545-572, 1991.

[22] R. M. Lewis and V. Torczon, “A globally convergent augmented Lagrangian pattern search algorithm for optimization with general constraints and simple bounds," SIAM Journal on Optimization, Vol. 12, pp. 1075-1089, 2002.

[23] K. Miettinen, M. M. Makela, and J. Toivanen, "Numerical comparison of some penalty-based constraint handling techniques in genetic algorithms”, Journal of Global Optimization, Vol.27, pp. 427-446, 2003.

[24] R. Baldick, Applied Optimization, Formulation and Algorithms for Engineering Systems, Cambridge University Press, May 2006, pp. 103158.

[25] D.G. Luenberger, Y. Ye, Linear and Nonlinear Programming, Springer, 3rd Ed Jun 2008 ISBN: 0387745025 pp. 402-405.

[26] Pardalos, P. M., Romeijn, and H. Edwin, Handbook of global optimization, vol. 2, Kluwer Academic, 2002.

[27] L. B. Kier, P. G. Seybold, and C.-K. Cheng, “Cellular Automata,” in Modeling Chemical Systems Using Cellular Automata: Springer Netherlands, 2005, pp. 9-38. 